\title{
PROF. DR. JURIJ KUNAVER, OSEMDESETLETNIK
}

Nenavadno visoka obletnica za tako mladostnega in vitalnega človeka, geografa, geomorfologa, pedagoga, jamarja, ljubitelja narave in še česa je verjetno nagrada za desetletja dolgo in neutrudno jubilantovo delovanje na vseh naštetih področjih. 13. junija 2013 si je na ramena zadel že deveti križ in prepričan sem, da ga bo nosil z enakim veseljem in lahkoto kot vse dosedanje. Pri tem mu bo pomagala njegova nemirna žilica, ki ga je že kot petnajstletnega fantiča zvabila v naravo, najprej med jamarje v Društvo za raziskovanje jam Ljubljana in nekoli-

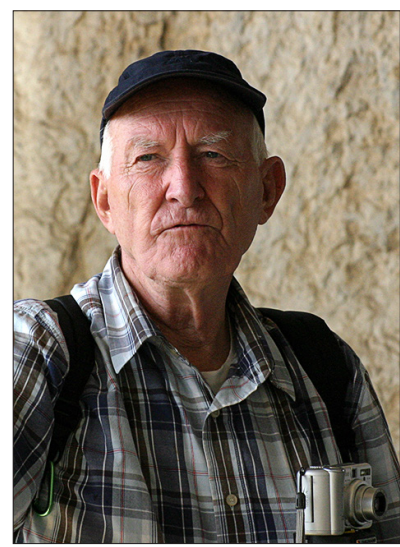
ko kasneje še v Zvezo tabornikov Slovenije. Doživljanje narave ter življenjski slog skavtske družine Kunaver z očetom Pavlom, mamo Henrieto ter štirimi, z neizčrpno energijo in radovednostjo nabitimi fanti, ga je skoraj samoumevno pripeljalo do študija geografije na takratni Prirodoslovno-matematični fakulteti ljubljanske univerze, na kateri je diplomiral leta 1958 z diplomskim delom o visokogorskem krasu vzhodnih Julijskih in Kamniško-Savinjskih Alp. Najprej je dve leti poučeval na ljubljanskem učiteljišču, leta 1961 pa kot asistent na Oddelku za geografijo Filozofske fakultete začel dolgoletno univerzitetno kariero. S posebno vnemo se je posvetil preučevanju drobnih kraških oblik na golih skalnatih tleh v visokogorju in svoje večletno naporno in včasih nevarno terensko delo uspešno prelil v doktorsko disertacijo z naslovom Geomorfološki razvoj Kaninskega pogorja s posebnim ozirom na razvoj glaciokrasa, ki jo je ubranil jeseni 1972.

Preučevanju krasa, posebno visokogorskega, se je profesor Kunaver neutrudno posvečal skozi celotno kariero in postal mednarodno ugleden poznavalec visokogorskega krasa. S prehodom na takratno Pedagoško akademijo Univerze v Ljubljani (1974-86) se je začel posvečati še didaktiki geografije, ki je bila v tistih časih pred velikimi izzivi, saj je bilo treba šolsko geografijo postaviti na nove temelje in to tudi uveljaviti v šolski praksi. Dve leti je opravljal zahtevno funkcijo dekana akademije (1977-79), v času, ko so začeli z gradnjo nove šole na današnji lokaciji za Bežigradom in je nato to nalogo izpeljal do konca kot predsednik gradbenega odbora.

Kot neutruden organizator in povezovalec različnih interesov v zapleteni mreži šolskega sistema je s tem delom nadaljeval po povratku na Oddelek za geografijo ljubljanske Filozofske fakultete (1986), kjer je prevzel vodenje katedre za didaktiko geografije in s tem pomemben delež skrbi za izobraževanje bodočih učiteljev in profesorjev geografije. Nekaj let je geomorfologijo in didaktiko geografije predaval tudi na Pedagoški fakulteti v Mariboru (1989-93), v letih 1989-97 tudi vojaško geografijo na katedri za obramboslovje na Fakulteti za družbene vede. Poleg vseh teh zadolžitev je 1992-94 'odslužil' še funkcijo predstojnika Oddelka za geografijo, ob vsem tem pa je napisal 
še vrsto poljudnoznanstvenih člankov za Geografski obzornik in Proteus ter takratno mladinsko revijo Pionir, kot soavtor sodeloval pri pripravi srednješolskih učbenikov in še bi lahko naštevali.

Osemdeseta in devetdeseta leta prejšnjega stoletja so bila nedvomno čas slavljenčevega največjega razcveta. Zelo aktivno je vrsto let sodeloval pri vsebinski in organizacijski prenovi šolske geografije (1996-98 kot predsednik Predmetne kurikularne komisije za geografijo), spodbujal učitelje in druge k aktivnejšemu udejstvovanju in povezovanju z namenom izboljšanja kvalitete poučevanja geografije na vseh nivojih izobraževanja. Znal si je pridobiti prizadevne sodelavke in sodelavce in skupaj so zmogli premakniti marsikaj, npr. začeti z organizacijo Ilešičevih dnevov, za katere je dal prav slavljenec leta 1985 pobudo in jih je nato vrsto let s sodelavci uspešno vodil. Bil je eden od organizatorjev prvega mednarodnega simpozija o didaktiki geografije v Sloveniji (Evropska dimenzija pouka geografije; 1993), leta 1991 je bil med ustanovitelji strokovne revije Geografija $v$ šoli, nato njen urednik in avtor vrste prispevkov. Njegova je bila pobuda za strokovna srečanja jugoslovanskih geomorfologov in leta 1986 je organiziral prvo tovrstno zborovanje v Bovcu, osem let je bil predsednik Zveze geografskih društev Slovenije (1980-88, 1980-84 še kot Geografsko društvo Slovenije), 1989-91 je bil predsednik Nacionalnega komiteja pri Zvezi geografskih društev Jugoslavije in nato 1991-94 predsednik Nacionalnega komiteja pri Zvezi geografskih društev Slovenije. V tej funkciji si je mdr. zelo prizadeval, da je bila Slovenija na 27. kongresu Mednarodne geografske unije v Washingtonu leta 1992 sprejeta med redne članice. Bil je tudi med ustanovitelji Geomorfološkega društva Slovenije leta 1998, vodil je številne mladinske raziskovalne tabore, zelo opazno je njegovo delovanje v Društvu učiteljev geografije Slovenije, v zadnjih letih tudi prizadevno delovanje na področju domoznanstva in geografije v bovški občini.

Po upokojitvi se naš slavljenec razdaja tudi na ljubljanski univerzi za tretje življenjsko obdobje, kjer slušateljicam in slušateljem z neizčrpno energijo na predavanjih in strokovnih ekskurzijah predstavlja geografske in druge značilnosti Slovenije in sosednjih dežel. Ob številnih priznanjih in nagradah, ki jih je profesor Kunaver prejel za svoje znanstveno in pedagoško delovanje, so zadovoljni obrazi rahlo utrujenih slušateljic in slušateljev po koncu ekskurzije najlepša nagrada za njegovo srčno delo za geografijo in iz vsega srca mu želimo, da bi mu zdravi geni še dolgo podpirali njegovo polno predanost slovenski geografiji. 